Environmental Restoration Division

ORNL Environmental Restoration Program

\title{
Migration of a Groundwater Contaminant Plume by Stratabound Flow in Waste Area Grouping 1 at Oak Ridge National Laboratory, Oak Ridge, Tennessee
}

R. H. Ketelle

R. R. Lee

Date Issued-August 1992

Prepared by Energy Division

Oak Ridge National Laboratory

Prepared for U.S. Department of Energy Office of Environmental Restoration and Waste Management under budget and reporting code EW 20

OAK RIDGE NATIONAL LABORATORY

Oak Ridge, Tennessee 37831-6285

managed by

MARTIN MARIETTA ENERGY SYSTEMS, INC.

for the

U.S. DEPARTMENT OF ENERGY

under contract DE-AC05-84OR21400

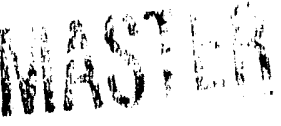




\section{Author Affiliations}

R. H. Ketelle and R. R. Lee are members of the Energy Division, Oak Ridge National Laboratory, Martin Marietta Energy Systems, Inc. 


\section{CONTENTS}

TABLES $\ldots \ldots \ldots \ldots \ldots \ldots \ldots \ldots \ldots \ldots \ldots \ldots \ldots \ldots \ldots \ldots$

FIGURES $\ldots \ldots \ldots \ldots \ldots \ldots \ldots \ldots \ldots \ldots \ldots \ldots \ldots \ldots \ldots \ldots \ldots$

EXECUTTVE SUMMARY $\ldots \ldots \ldots \ldots \ldots \ldots \ldots \ldots \ldots \ldots \ldots \ldots \ldots \ldots$

1. INTRODUCTION $\ldots \ldots \ldots \ldots \ldots \ldots \ldots \ldots \ldots \ldots \ldots \ldots \ldots \ldots \ldots$

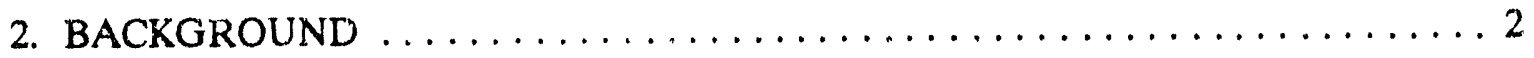

3. CONCEPTUAL MODEL DESCRIPTION ................. 4 3.1 STRATIGRAPHY OF THE CONTAMINANT MIGRATION ZONE . . . . 6

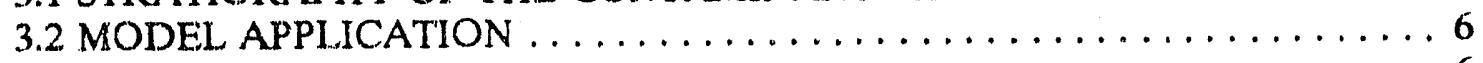

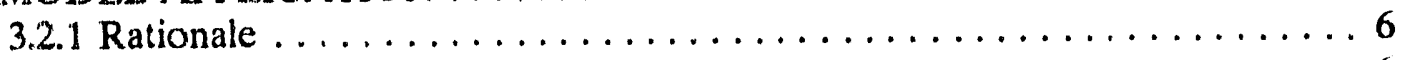

3.2.2 Methodology . . . . . . . . . . . . . . . . . . . 6

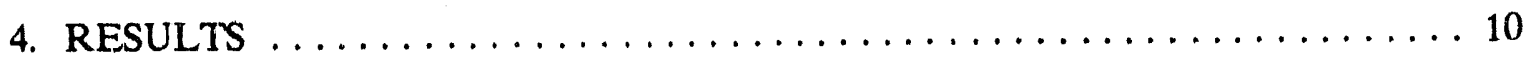

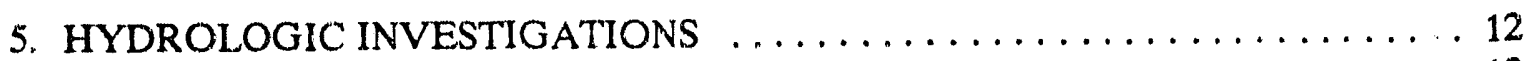

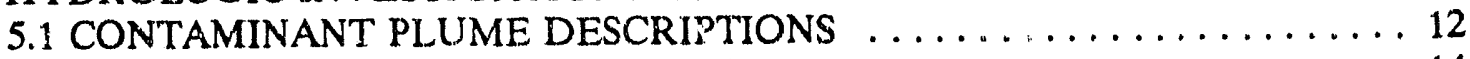

5.2 CONTAMINANT PLUME ANALYSIS $\ldots \ldots \ldots \ldots \ldots \ldots \ldots \ldots \ldots \ldots$

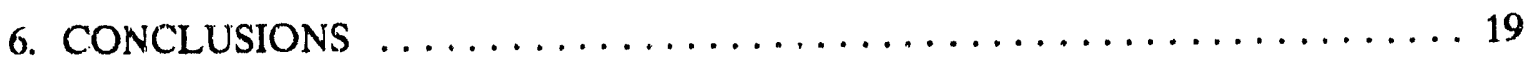

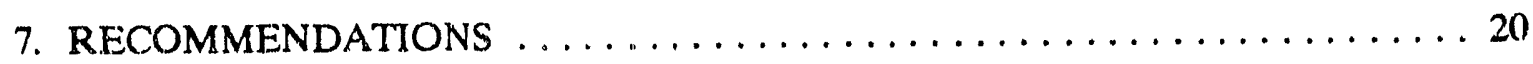

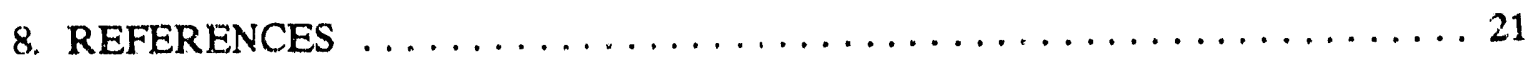

\section{DISCLAIMER}

This report was prepared as an account of work sponsored by an agency of the United States Government. Neither the United States Government nor any agency thereof, nor any of their employees, makes ariy warranty, express or implied, or assumes any legal liability or responsibility for the accuracy, completeness, or usefulness of any information, apparatus, product, or process disclosed, or represents that its use would not infringe privately owned rights. Reference herein to any specific commercial product, process, or service by trade name, leademark, manufacturer, or otherwise does not necessarily constitute or imply its endorsement, recommendation, of favoring by the United States Government or any agency thereof. The views and opinions of authors expressed herein do not necessarily state or reflect those of the United States Government or any agency thereof. 


\section{TABLES}

1 Interval radiological sampling results from core hole $\mathrm{CH}-8 \ldots \ldots \ldots \ldots$

2 Historical and recent radiological analytical results for storm drain outfalls 341 and 342 , well 812 , piezometer $539 \ldots \ldots \ldots \ldots$

3 Storm drain network analytical results $\ldots \ldots \ldots \ldots \ldots \ldots \ldots \ldots \ldots$ 


\section{FIGURES}

1 Idealized block diagram of stratabound pathway concept $\ldots \ldots \ldots \ldots \ldots \ldots$

2 WAG 1 core holes used to establish stratigraphic control core hole $\mathrm{CH}-8 \ldots \ldots \ldots \ldots \ldots \ldots \ldots \ldots \ldots \ldots$

3 Three-panel isometric perspective of core hole data used to predict the outcrop location of the contaminated stratum in First Creek ...........9

4 Locations of contamination in the western portion of WAG 1 and interpreted plume configuration $\ldots \ldots \ldots \ldots \ldots \ldots \ldots \ldots$

$5 \quad$ Hydrogeologic cross section of head and contminant concentrations for selected wells and First Creek ...................... 15

6 Gross beta contamination in contaminant plume, sampled storm drains, and storm drain outfalls . . . . . . . . . . . . . . 17 


\section{EXECUTIVE SUMMARY}

The discovery of radiologically contaminated groundwater in core hole $\mathrm{CH}-8$ in the western portion of Waste Area Grouping (WAG) 1 at Oak Ridge National Laboratory (ORNL) prompted a detailed investigation to identify the contaminant plume. Utilizing a working hypothesis of stratabound groundwater flow and contaminant transport, investigators analyzed existing subsurface geologic data to predict the contaminant plume discharge location in First Creek and locations of contaminated groundwater seepage into storm drains. The hypothesis states that differential lithologic/fracture conditions lead to the development of preferred flow and transport pathways, of discrete vertical extent, which may not be coincident with the hydraulic gradient. Leakage out of the stratabound pathway is a minor component of the overall plume configuration.

Results of the analysis indicate that application of the stratabound pathway hypothesis accurately predicted the plume discharge location in First Creek, which was $65^{\circ}$ oblique to the general gradient in that portion of WAG 1. Plume identification subsequently provided an explanation for historical contamination in WAG 1 piezometers and water quality wells which previously were not understood. Analysis of the subsurface storm drain in the vicinity of the plume also explained the historical contamination in storm drain outfalls to First Creek and verified the comparatively minor role of upward leakage out of the stratabound pathway to the water table as described by the hypothesis.

Characterization of a groundwater contaminant plume in the western portion of WAG 1 at ORNL will be used as input to remediation alternatives and for additionai investigations to more fully describe both the three-dimensional character of the plume and its source location. The development of a highly accurate, predictive capability in groundwater contaminant migration at ORNL, dernonstrated by the results of this study, will be applied to ongoing numerical groundwater analyses at ORNL and at other WAGs on the Oak Ridge Reservation. 


\section{INTRODUCTION}

This report describes results of a study performed as part of the Martin Marietta Energy Systems, Inc., staff technical oversight in Remedial Investigation/Feasibility Studies (RI/FS) being conducted for the Environmental Restoration (ER) Program at Oak Ridge National Laboratory (ORNL). This report describes the geologic and hydrologic methods used to identify the three-dimensional nature of a groundwater contaminant plume in Waste Area Grouping (WAG) 1 from a single point datum. One element in an overall conceptual model for groundwater flow in WAG 1 is described which apparently controls and was used to predict plume migration from a source area near core hole $\mathrm{CH}-8$ located south of the ORNL cafeteria, Building 2010, to the plume discharge area near First Creek. The predicted plume discharge location is compared with analytical results of radiological contamination in First Creek and the general direction of contaminant plume migration anticipated based on the water table configuration. Locations of plume discharge to the WAG 1 storm drain network are identified. Remedial measures to limit such discharge and additional field activities to more accurately describe plume configuration are recommended. Characteristics of the shallow groundwater system that are being used in flow-field conceptual model development for incorporation in numerical simulation are also described.

The technical staff from $\mathrm{CH} 2 \mathrm{M}$ Hill [subcontractor to Bechtel National, Inc. (BNI) for the WAG $1 \mathrm{RI} / \mathrm{FS}$ ] provided pertinent data and information that enabled this study to be performed. Technical exchange and peer review of this report by $\mathrm{CH} 2 \mathrm{M}$ Hill staff are acknowledged as is peer and programmatic review by ORNL's Environmental Sciences Division and ER Program staff, respectively. In keeping with engineering survey and drilling convention, numerical values from field studies are given in British units. In keeping with laboratory analytical convention, radiological and physicochemical values are given in SI units. 


\section{BACKGROUND}

As part of the Phase I RI/FS studies in WAG 1 at ORNL, rock core drilling has taken place to accurately describe subsurface geologic conditions and to permit the performance of subsurface hydrologic tests. In June 1991, rock core drilling of CH-8 (located immediately south of the ORNL cafeteria) revealed radiologically contaminated conditions in the uppermost portions of the bedrock (nominally $12 \mathrm{ft}$ below ground surface). Radiological contamination increased with depth, so $\mathrm{CH}-8$ was only drilled down to $53.5 \mathrm{ft}$. A Westbay multilevel groundwater sampling device was installed in the hole, and no down-hole geophysical data were obtained. Table 1 contains results of radiological analyses of groundwater samples obtained from the Westbay device in $\mathrm{CH}-8$; these results indicate that the highest levels of gross beta/gamma contamination occur in intervals 2 and 3,20 to $30 \mathrm{ft}$ below the bedrock surface and a similar depth below the local water table. 


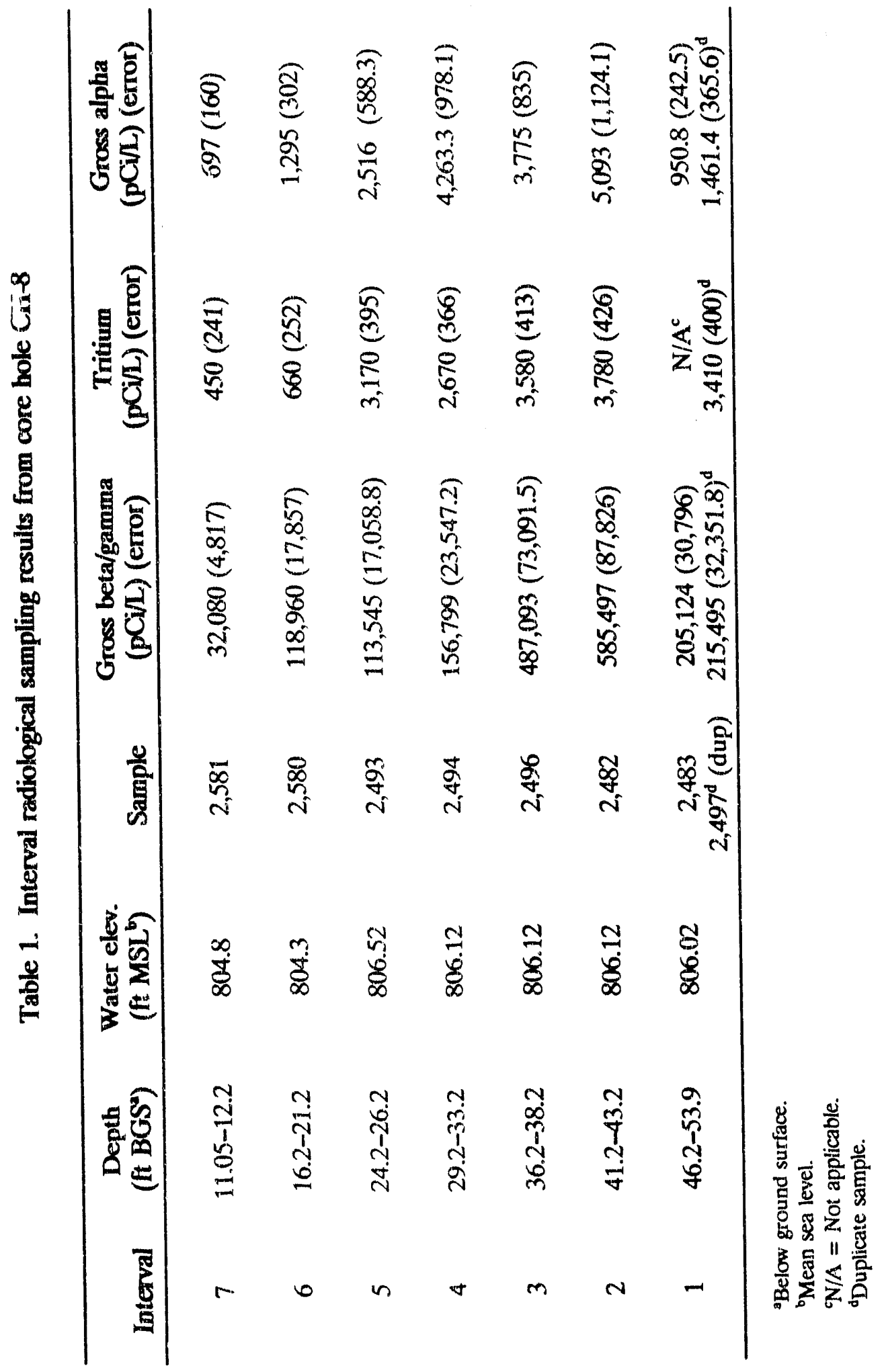




\section{CONCEPTUAL MODEL DFSCIRIPTION}

In general, groundwater occurrence and movement in WAG 1 consist of recharge in unpaved areas and outleakage from various subsurface pipes. Groundwater movement is largely along the interface of soil and bedrock with local channelized flow within pipe trenches and in fractures and cavities in bedrock. Because of large hydraulic conductivity contrasts between adjacent strata and the occurrence of discrete zones of preferred groundwater flow, flow solely along the water-table gradient is unlikely even in the general case. In areas where the top of the saturated zone occurs below the bedrock weathering interface, recharge fluxes enter fractures and flow occurs through bedrock. The interpretation presented here demonstrates how detailed geologic analyses in groundwater studies can provide a framework of predictability for contaminant plume migration which is not readily explained assuming a conventional equivalent porous medium-flow field.

The concept described in this analysis is that of the stratabound pathway, which is generally illustrated in an idealized and simplified block diagram (Fig. 1). In simplest terms, the concept incorporates differential subsurface lithologic/fracture conditions that operate as discrete, preferred-flow and transport pathways compared with superjacent and subjacent lithologies. The presence of these pathways results in a preferred strike-parallel direction of flow and transport that is generally not coincident with the overall hydraulic gradient. While vertical leakage out of the stratabound pathway is considered to occur, its contribution to overall groundwater flow is cornparatively minor. This concept readily explains many soluteplume-flow paths observed in bedrock and saprolite zones on the Oak Ridge Reservation (ORR). Local plumes in bedrock tend to be quite narrow, and often solutes migrate in pathways oriented oblique to the general hydraulic gradient.

Stratabound, preferred flow has long been known as a viable concept in the mining industry to describe the dominant control of ore mineralization in certain geologic settings. Lee and Ketelle (1987) were the first to describe and document the viability of stratabound, preferred flow pathways in ORR groundwater investigations in the Knox Group underlying Chestnut Ridge. Subsequent groundwater studies on ORR (Lee and Ketelle 1988; Lee et al. 1989) indicate that the concept is also applicable in the Conasauga Group underlying Bear Creek Valley. The configuration of the S-3 Ponds contaminant plume (Geraghty and Miller 1990 ) is further evidence supporting the concept in the Conasauga Group in Bear Creek Valley. In the Pits and Trenches Area in Melton Valley (WAG 7), Olsen et al. (1983 and 1986) report that discrete fractures, conduits, or strata carry most of the radioactive seepage from trench 7 . 


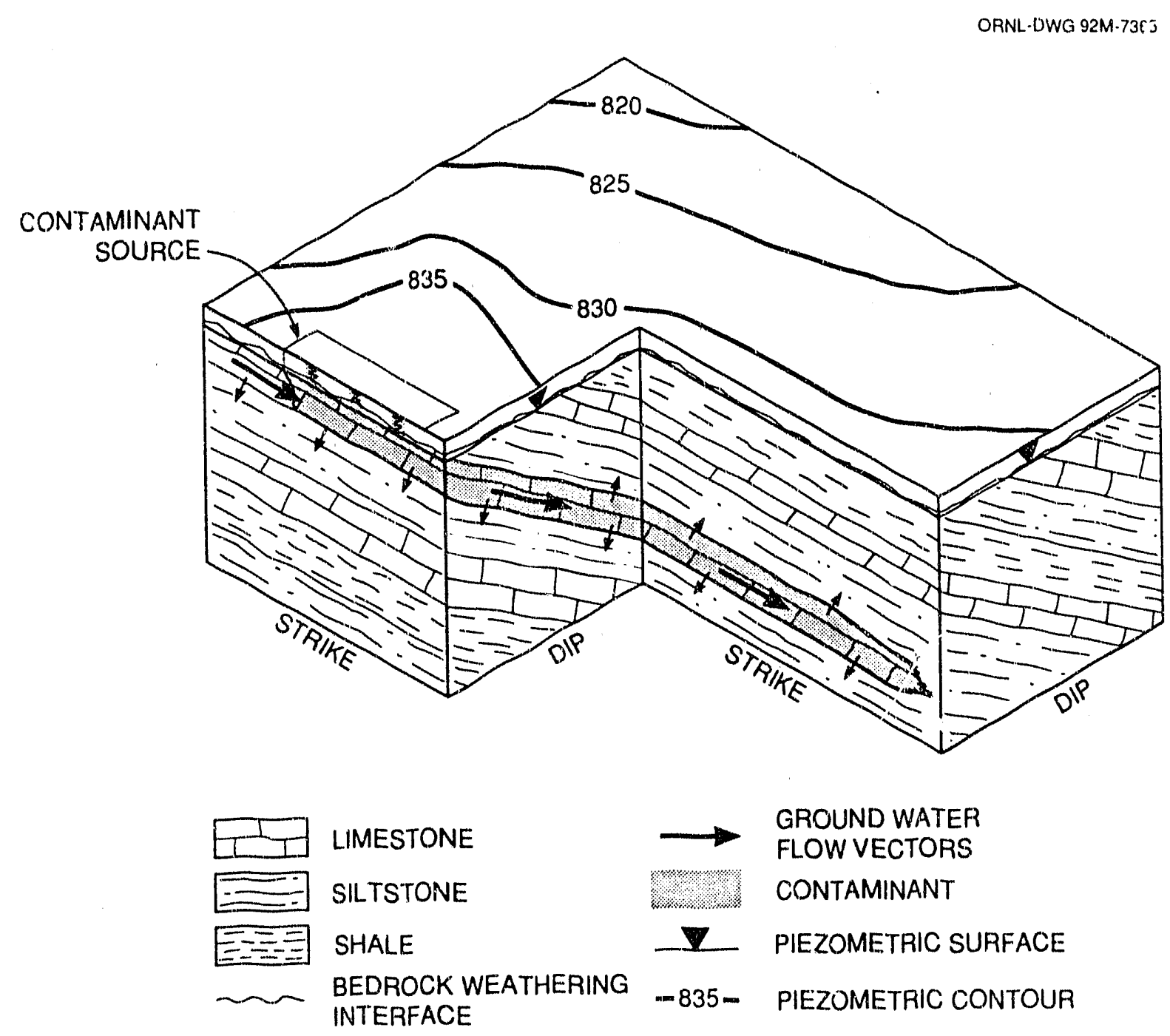

Fig. 1. Idealized block diagram of the stratabound pathway concept. 


\subsection{STRATIGRAPHY OF THE CONTAMINANT MIGRATION ZONE}

The ground surface location of $\mathrm{CH} \cdot 8$ is in Unit $\mathrm{E}$ of the Middle Ordovician Chickamauga Group. Unit $\mathrm{E}$ is lithologically heterogeneous, generally consisting of dark gray shaley siltstone, nodular limestone, and admixtures of both rock types at various scales.

The on-site geologist's core log describes a dark olive gray siltstone that is roughly $10 \mathrm{ft}$ thick (approximately 19 to $30 \mathrm{ft}$ below ground surface) separating two nodular limestone units. With this lithologic description, which is extremely common to much of Unit E, and with the limited amount of $\mathrm{CH}-8$ rock core available for correlation with existing core $(42 \mathrm{ft})$, confident placement of the $\mathrm{CH}-8$ contaminated zone with respect to the stratigraphic section is difficult. However, with careful correlation of thin stratigraphic units with existing Chickamauga Group rocks, accurate stratigraphic placement can be determined.

\subsection{MODEL APPLICATION}

This section describes the rationale for using stratigraphy and geologic structure to apply the stratabound pathway concept for projecting contaminated subsurface bedrock units from CH-8 to their outcrop location in First Creek. The steps in applying the methology that lead to the predicted location of the bedrock units in First Creek are also described.

\subsection{Rationale}

The problem of identifying the precise location of the CH-8 contaminated strata in First Creek was readily divisible into two sequential components: (1) identifying the contaminated zone in $\mathrm{CH}-8$ with respeci to the stratigraphic section (establishing stratigraphic control), and (2) projecting that interval to its outcrop location in First Creek.

Because of local variations in the azimuth of bedrock strike in WAG 1, along-strike projections of subsurface stratigraphy to relatively distant locations (nominally $1000 \mathrm{ft}$ ) can result in considerable discrepancies between a projected datum and a known datum. Similarly, minor variations in the angle of bedding dip across WAG 1 and the presence or absence of certain discrete beds can lead to apparent differences in unit thickness. When precision is required, up- or down-dip projections through a significant thickness of the stratigraphic section can also lead to discrepancies between a projected datum and a known datum. Because high-resolution subsurface stratigraphic control is available in WAG 1, a combined triangulation method using along-strike and up-dip projections through minimal section thickness followed by field verification was considered to provide the greatest projection accuracy.

\subsubsection{Methodology}

The limited depth of $\mathrm{CH}-8$ made identification of the precise location of the contaminated zone in the stratigraphic section somewhat complicated. Geometric and trigonometric relations were made with known stratigraphy from previously drilled core holes. Core holes used in establishing stratigraphic control are shown in Fig. 2. 


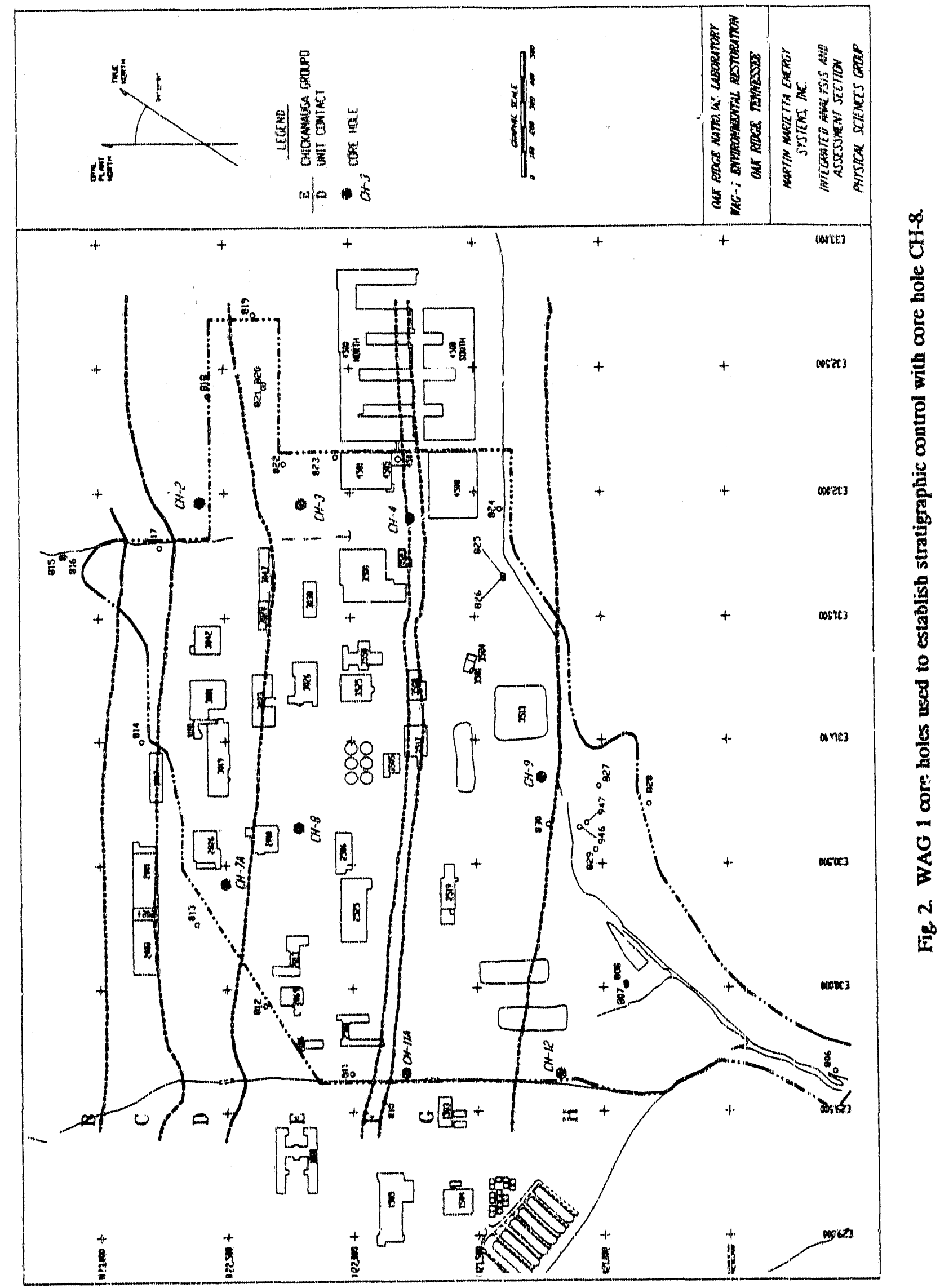


Three strike-normal cross sections were prepared from existing rock core data approximately coincident with First, Third, and Fifth streets in WAG 1. Figure 3, a threepanel isometric perspective of those cross sections, illustrates the steps followed in problem solution. While all available WAG 1 core hole data were used in preparing each cross section, only those data pertinent to the CH-8 contamination problem are included in Fig. 3 . The ste $p$ s involved in pojecting the $\mathrm{CH}-8$ contaminated zone to First Creek are described in the following paragraphs.

Comparisons among the previously drilled core holes $\mathrm{CH}-2, \mathrm{CH}-3$, and $\mathrm{CH}-7$ suggested an approximate, anticipated depth of the Chickamauga Group D/E contact at the CH-8 location. ' $h^{\prime}$ ith that estimate, rock core from $\mathrm{CH}-8$ was transported to Building 7042 to correlate $\mathrm{CH}-8$ with known stre igraphy from core holes $\mathrm{CH}-3$ and $\mathrm{CH}-4$. "he following stratigraphic pick was made: $\mathrm{CH}-8,19 \mathrm{ft} ; \mathrm{CH}-3,52.5 \mathrm{ft}$; and $\mathrm{CH}-4,290 \mathrm{ft}$. This horizon marks the top of the 10-ft-thick dark olive gray siltsione in $\mathrm{CH}-8$ that overlies an $11-\mathrm{ft}$-thick limestone bed in $\mathrm{CH}-4$. The limestone, of apparent bivisermal (algal) origin, is locally thin (e.g., in $\mathrm{CH}-3$ ) but is present in $\mathrm{CH}-8$. It is this limestone bed that exhibited the highest levels of contamination in $\mathrm{CH}-8$ (Table 1, intervals 2 and 3 ) and was considered to be the stratabound preferred groundwater flow pathway.

Using key stratigraphic horizons from positions higher in the stratigraphic section than the $\mathrm{D} / \mathrm{E}$ contact (e.g., the unit $\mathrm{E} / \mathrm{F}$ contact and geophysical log markers), investigators correlated $\mathrm{CH}-4$ with $\mathrm{CH}-11 \mathrm{a}$, which is located near First Creek. By assuming a constant unit stratigraphic thickness throughout ORNL, the positions of the unit D/E contact and the stratigraphic pick, neither of which were penetrated in $\mathrm{CH}-11 \mathrm{a}$, were estimated. From these entimates, the reported average angle of bedding dip from the $\mathrm{CH}-11 \mathrm{a}$ drilling $\log \left(32.3^{\circ}\right)$ was uniformly applied to perform an up-dip projecion of the subsurface position of the $D / E$ contact to its outcrop location in First Creek.

Field checking of the projected position of the D/E contact at depth to its outcrop position in First Creek determined that the subsurface projection was accurate to within feet. A simple trigonometric problem was then solved to predict the outcrop location of the CH-8 contaminated zone, an interval from about 43 to $55 \mathrm{ft}$ southeast of the D/E contact, assuming a CH-4 limestone thickness of $11 \mathrm{ft}$. 


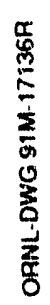
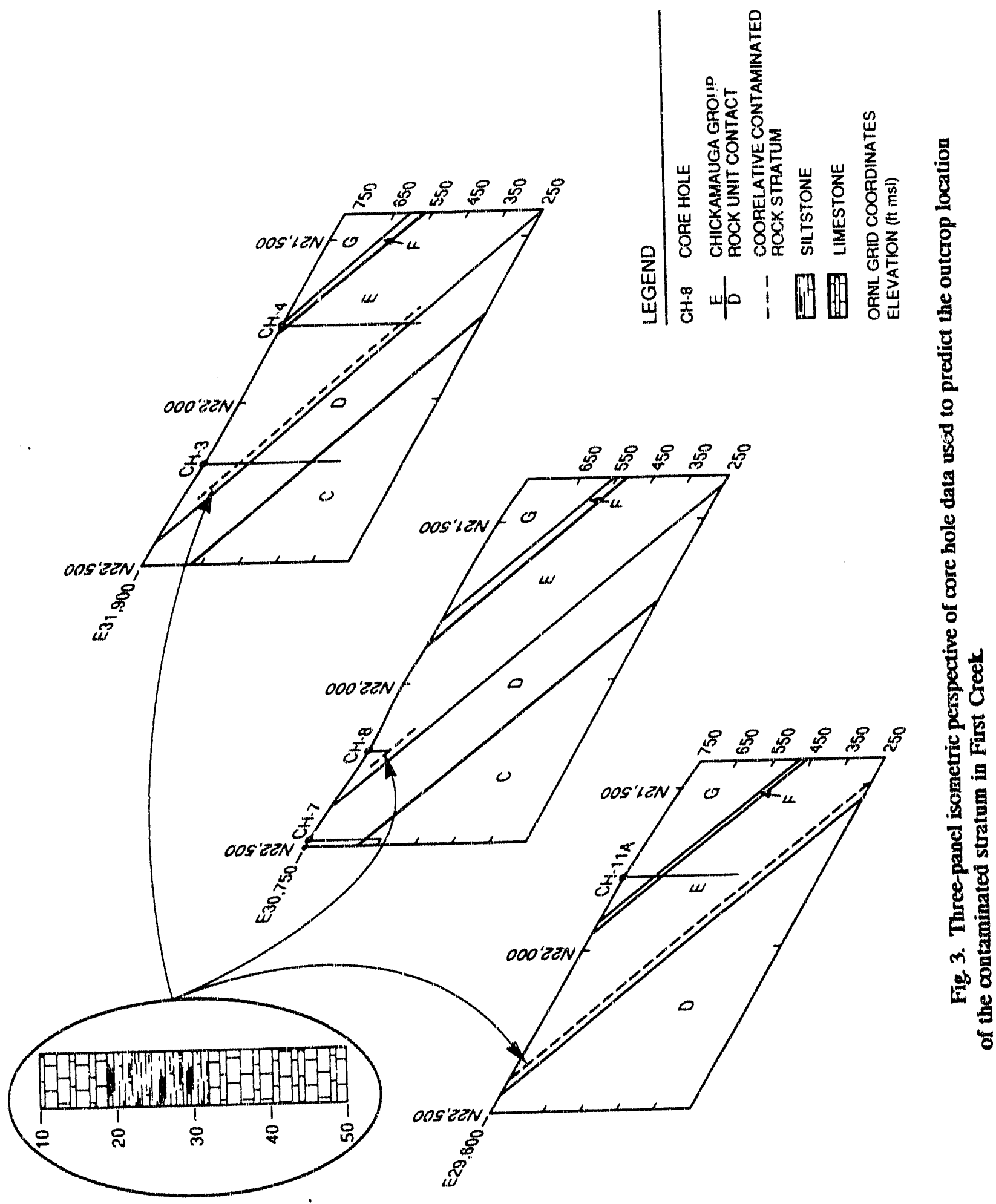


\section{RESULTS}

Figure 4 shows the locations of surface water seeps in First Creek where significant radiological contamination (filtered gross beta) was found. For clarity, the more than 30 sampled surface water locations that did not exhibit radiological contamination are not shown. These locations include five samples obtained roughly $10 \mathrm{ft}$ apart upstream and downstream of the locations shown in Fig. 4. The piezometric surface is based on measurements obtained on Septenber 30 and October 1, 1991, by a team from CH2M Hill/Bechtel National, Inc.

The two northernmost seeps are $30 \mathrm{ft}$ and $50 \mathrm{ft}$ southeast of the $\mathrm{D} / \mathrm{E}$ contact with values of 220 and $42 \mathrm{pCi} / \mathrm{L}$ gross beta (filtered), respectively. An anomalously high $4400-\mathrm{pCi} / \mathrm{L}$ gross beta (unfiltered) and $<25-\mathrm{pCi} / \mathrm{L}$ gross beta (filtered) sample at $53 \mathrm{ft}$ southeast of the $\mathrm{D} / \mathrm{E}$ contact is not readily interpretable; however, it surgests radionuclide adsorption to seep sediments from past groundwater discharge but an absence of such discharge at the time of sampling. This was the location identified as the likely discharge location of the limestone bed before sample acquisition. Tritium is not present at any of the sample locations.

Contamination in First Creek is almost precisely within the interval predicted by the geologic analysis and the stratabound concept. If we assume that First Creek and $\mathrm{CH}-8$ contamination are related, migration is parallel to geologic strike and approximately $65^{\circ}$ oblique to the hydraulic gradient as shown by the shaded region in Fig. 4. Migration is also outside the western boundary of WAG 1. 


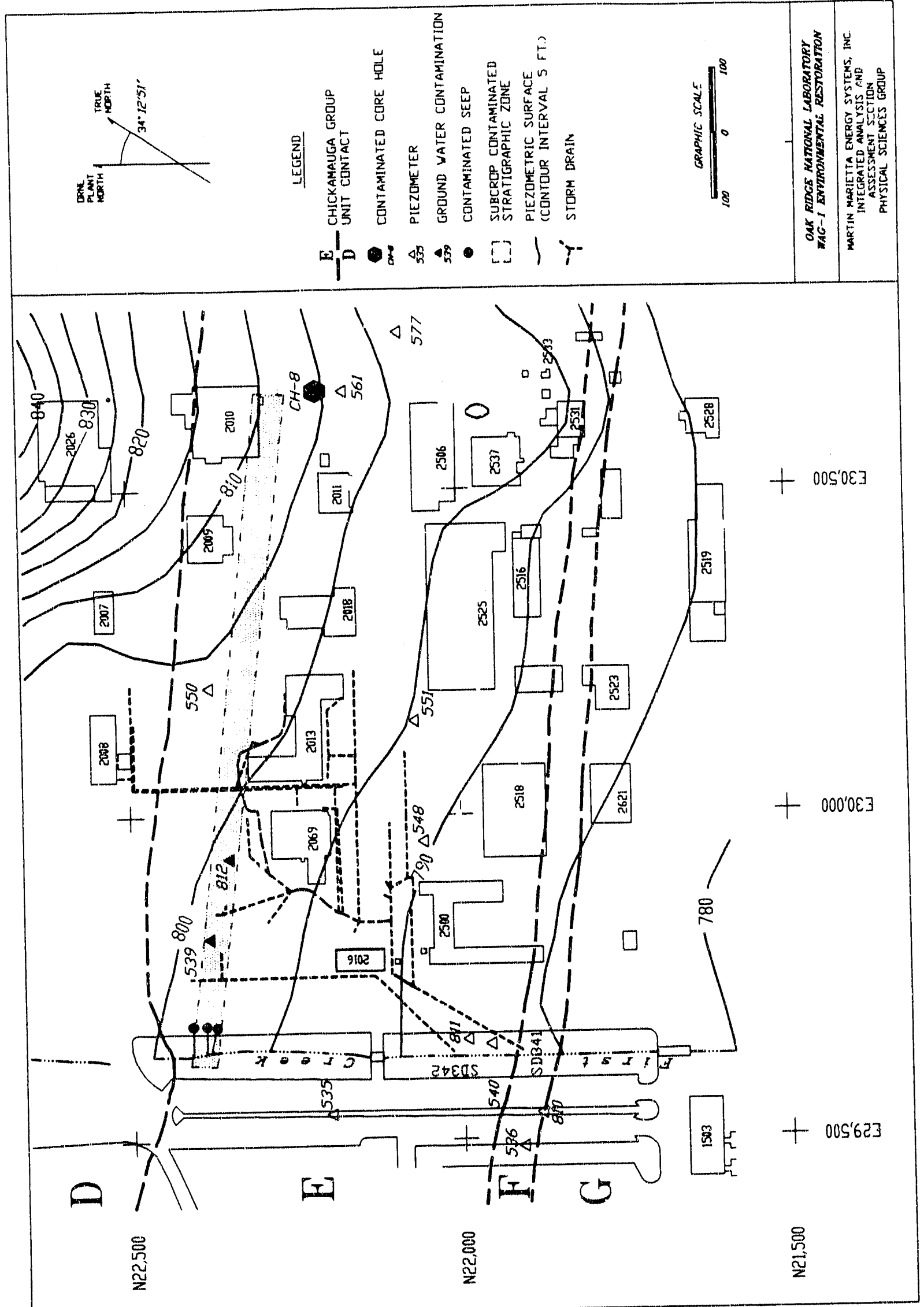

总 


\section{HYDROLOGIC INVESTIGATIONS}

The identification of First Creek contamination in the location predicted by the stratabound groundwater flow concept led to further investigations of groundwater contamination in the western portion of WAG 1. The purpose of these investigations was to describe a contaminant plume and possibly identify a contaminant source. This section gives historical background information about groundwater contamination in the western portion of WAG 1 that further supports the stratabound contaminant migration shown in Fig. 4.

\subsection{CONTAMINANT PLUME DESCRIPTIONS}

Hydrogeologic investigations in WAG 1 related to the Remedial Action Program (predecessor to ER) were initiated in 1985. These began with the installation of piezometers to enable the measurement of basic aquifer properties, the monitoring of water level fluctuations, and the collection of water samples for scoping analysis of groundwater contamination. Data obtained from the piezometer construction were used to design the existing network of wells used to monitor groundwater quality along the perimeter of WAG 1 .

Since 1986 radiological contamination, including alpha- and beta-emitting radionuclides and tritium, has beeri detected in groundwater and storm drain discharge water from the western perime $c^{\prime}$ \& $\&$ WA 1 originating north of Central Avenue. Figure 4 shows the locations of all piezometers sampled in the $\mathrm{CH}-8$ radiological contamination invest:gation in the western portion of WAG 1 . Those found to be contaminated are highlighted.

Analytical results for historical and recent radiological analyses from well 812, piezometer 539, and First Creek outfalls 341 and 342 are presented in Table 2. Analytical results for a contaminant scoping water sample collected from piezometer 539 (located near the western edge of WAG 1) showed radiological contamination in 1986 (Table 2). Consequently, a water quality well (well 812) was sited and constructed nearby on the WAG 1 boundary. This well has shown radiological contamination throughout its monitoring record. Before this analysis, radiological contamination in these two piezometers had never been explained adequately. In 1988 the storm drains feeding outfalls 341 and 342 were lined using the InsituForm process in an attempt to exclude the contaminated groundwater from discharging to First Creek via these drains. The data in Table 2 indicate that the lining job did not completely eliminate radiological discharges to First Creek via outfalls 341 and 342.

Figure 4 also shows the location of the storm drains that discharge via outfalls 341 and 342 to First Creek. Many crossings and apparent interconnections exist within the storm drain systems. Connections and interllows undoubtedly occur between branches of the storm drain trenches and trenches of other utilities not shown on Fig. 4. Most of the drain pipes discharging through outfalls 341 and 342 were lined with InsituForm in about 1988; however, construction records indicate that portions of the pipeline north of Building 2013 and the section extending toward piezometer 539 were not completely lined. 


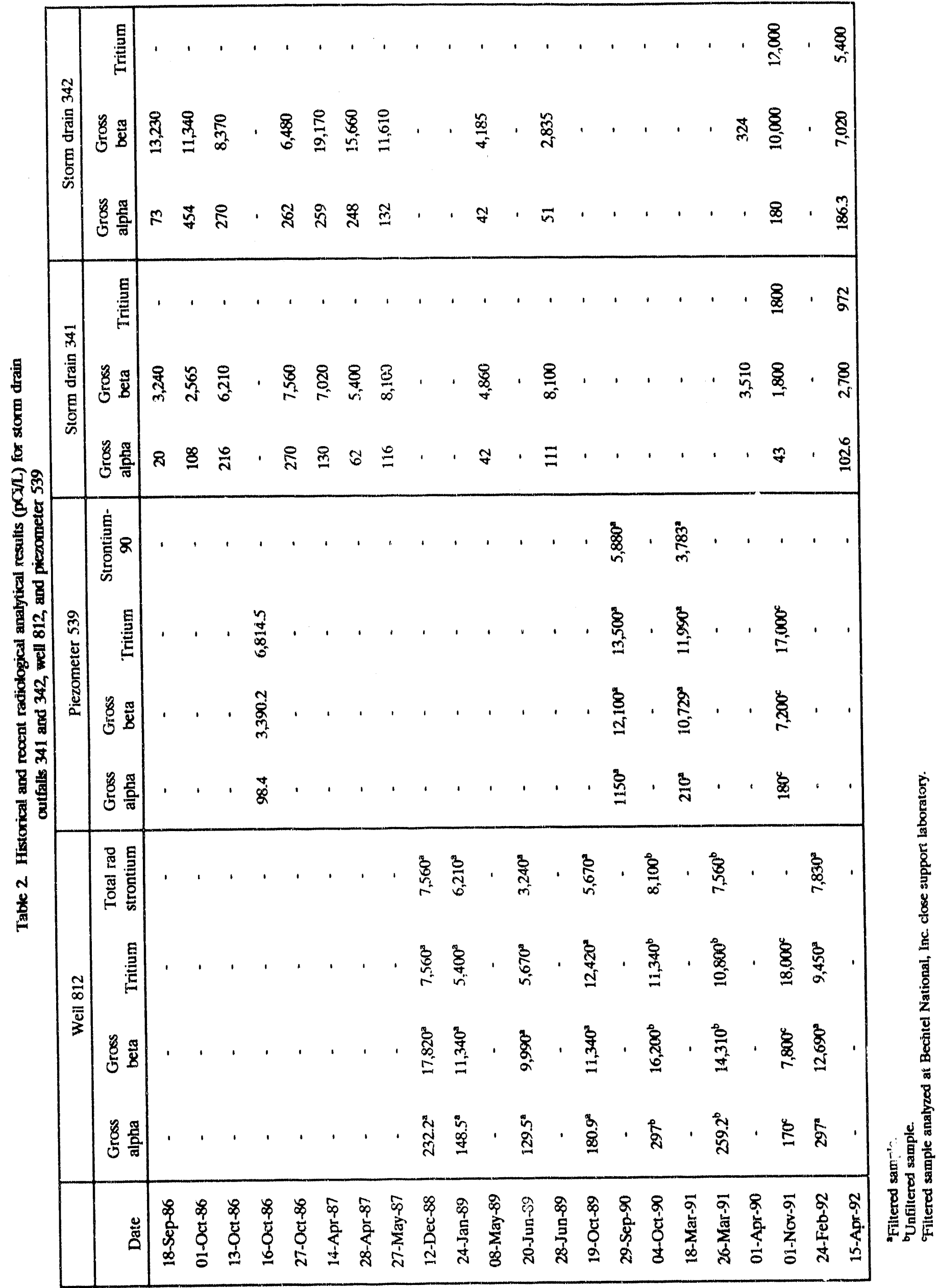


To investigate possible locations of contaminant influx into the storm drain system, grab samples were obtained from the storm drain network at access locations in the vicinity of Building 2013 for radiological analysis. Sampling occurred more than $72 \mathrm{~h}$ after a precipitation event to minimize sample dilution. It should be noted that the engineering drawings of the storm drain network did not always coincide with field observations, and not all access locations are included in the engineering drawings.

Figure 5 shows the locations of storm drain and outfall sampling and the analytical results of gross beta activity in picocuries per liter. Analytical results for all analytes are listed in Table 3. Table 3 also lists field physicochemical results and compares storm drain invert elevations and groundwater elevations from September 30 and October 1, 1991, measurement. These resuits indicate that the plume is discharging into the storm drain network to the north of Building 2013 and along First Street and that contaminants are discharging in the piezometer 539 seep. The analytical results and the apparent storm drain system connections suggest that the Building 2013 storm drains discharge via outfall 341 and that the First Creek storm drain discharges via outfall 342 .

The comparison of storm drain invert elevations and low-base groundwater elevation in Table 3, in addition to observed seepage into the storm drains, indicates that plume discharge into the storm drain network in the western portion of WAG 1 occurs continually. Also apparent in Table 3 is a relation between field physicochemical and analytical results which shows that radiologically contaminated samples also have values of conductance of 0.20 and greater and values of $\mathrm{pH}$ less than 8.0 .

\subsection{CONTAMNANT PLUME ANALYSIS}

Figure 6 is a strike-parallel, scaled cross section of the shallow subsurface showing radiological contaminant concentrations (picocuries per liter, filtered) in $\mathrm{CH}-8$ from the Westbay sampling intervals, in a storm drain catchment basin north of Building 2013, and in piezometers along the contaminant plume pathway and in First Creek. The maximum, scaledhead value tensors from isolated intervals indicate that the discharge pressure gradient from CH-8 to First Creek is greater than the vertical pressure gradient within $\mathrm{CH}-8$. This gradient distribution, coupled with weathered bedding planes and strike-set fractures, results in plume evolution within the stratigraphic zone in a direction nearly orthogonal to the general observed head surface rather than along the conventionally interpreted flow lines.

Minor vertical leakage of contaminant along the preferred, lateral-migration pathway (as shown in Fig. 1) is likely responsible for contaminants in piezometer 539 , well 812 , and the piezometer 539 seep. Similar leakage to the pictured storm sewer (M-15, which discharges to First Creek via outfall 341) is responsible for high-contaminant concentrations in that outfall. Because measured water elevations in Fig. 5 represent low-base conditions, the degree of connection between groundwater and the storm drain is likely greater during highbase conditions.

Incompletely lined portions of the storm drain system in the vicinity of Building 2013 and piezometer 539 are considered to be the source of radiological contaminants in storm drain outfalls 341 and 342 . Note that water was observed to be upwelling into and exiting from sample location $\mathrm{M}-15$. These storm drains appear to capture the top of the plume and may provide a local constant-head boundary that is intercepting the plume and may retard its continued expansion in a westward direction. 
品

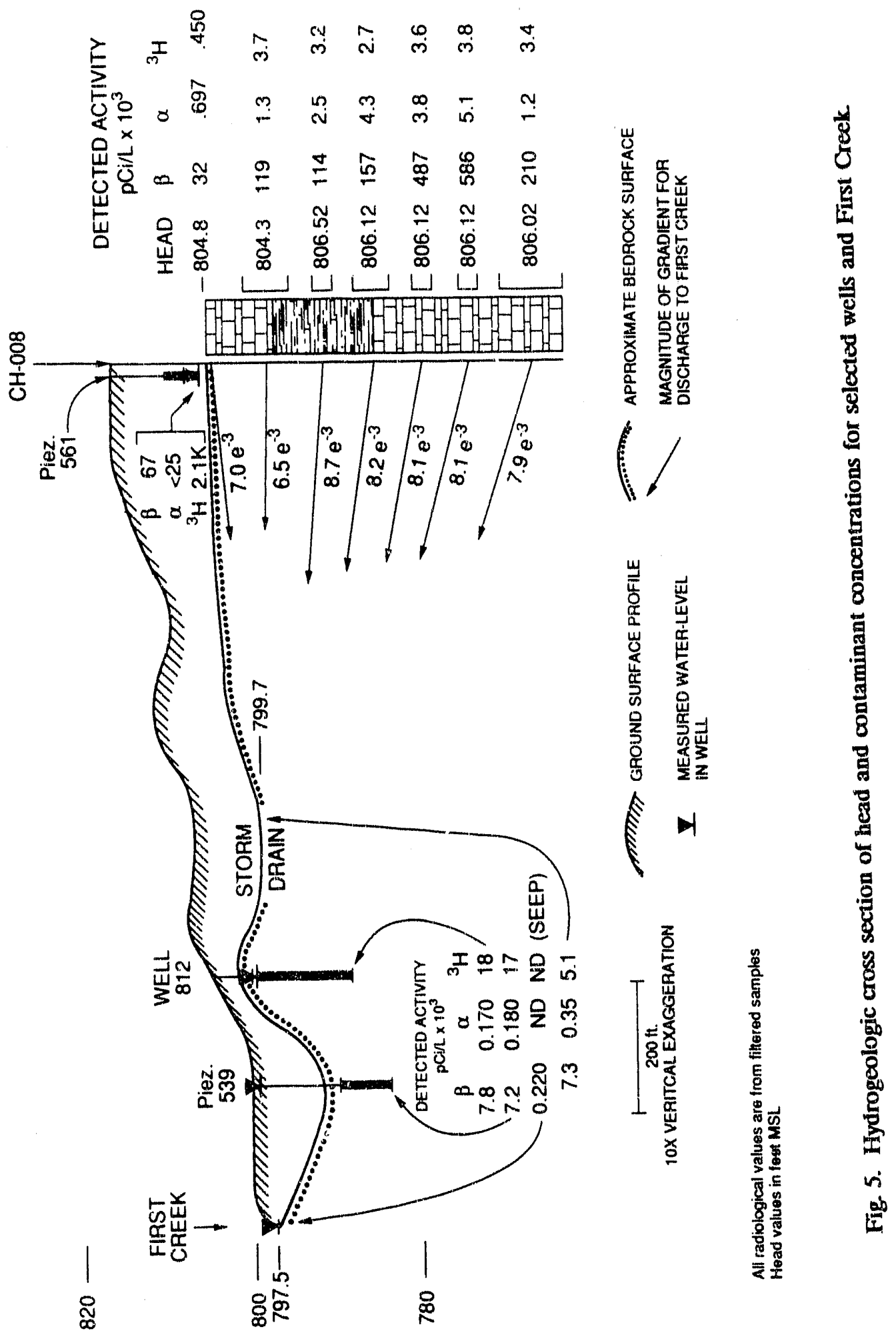




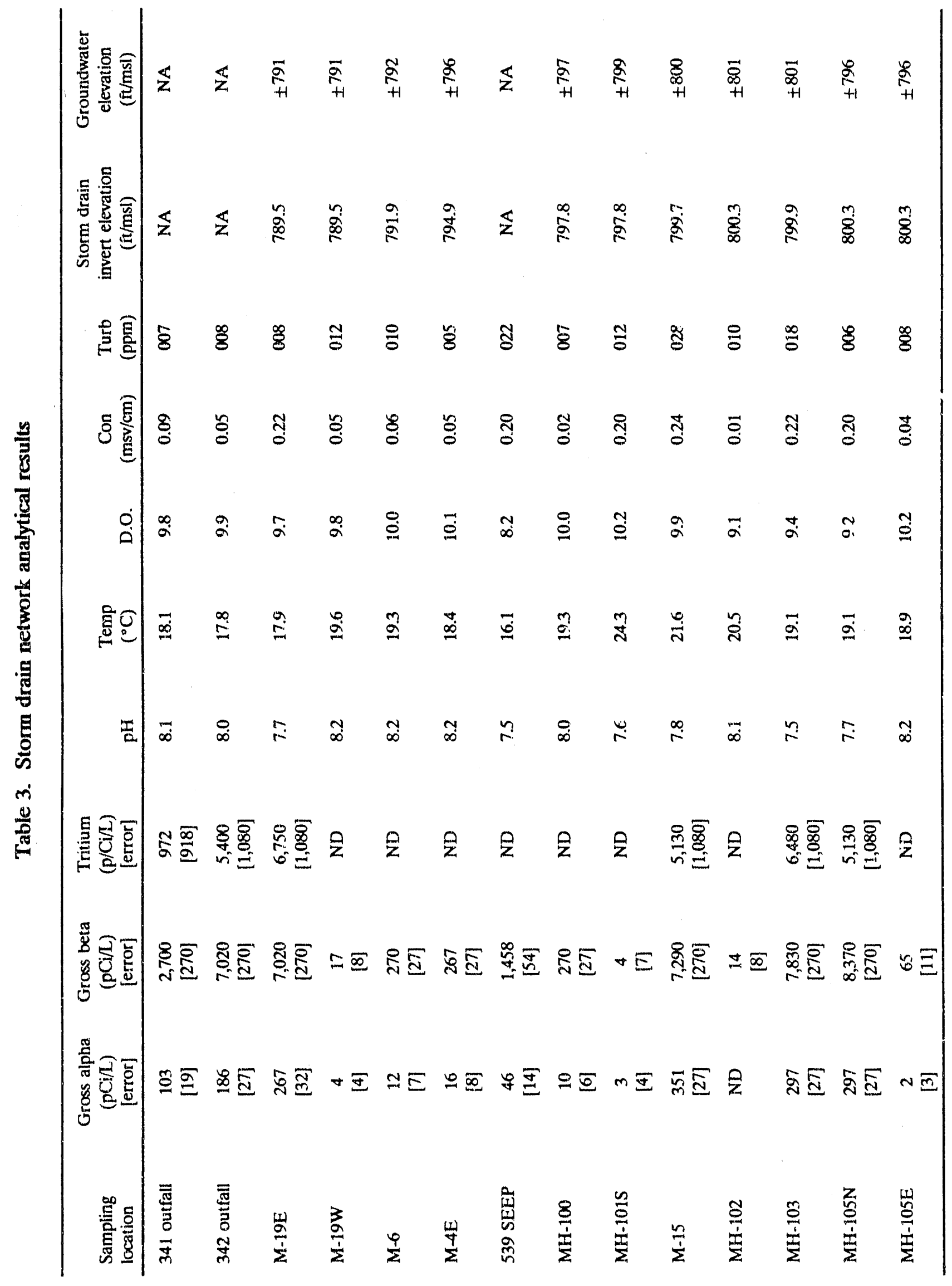




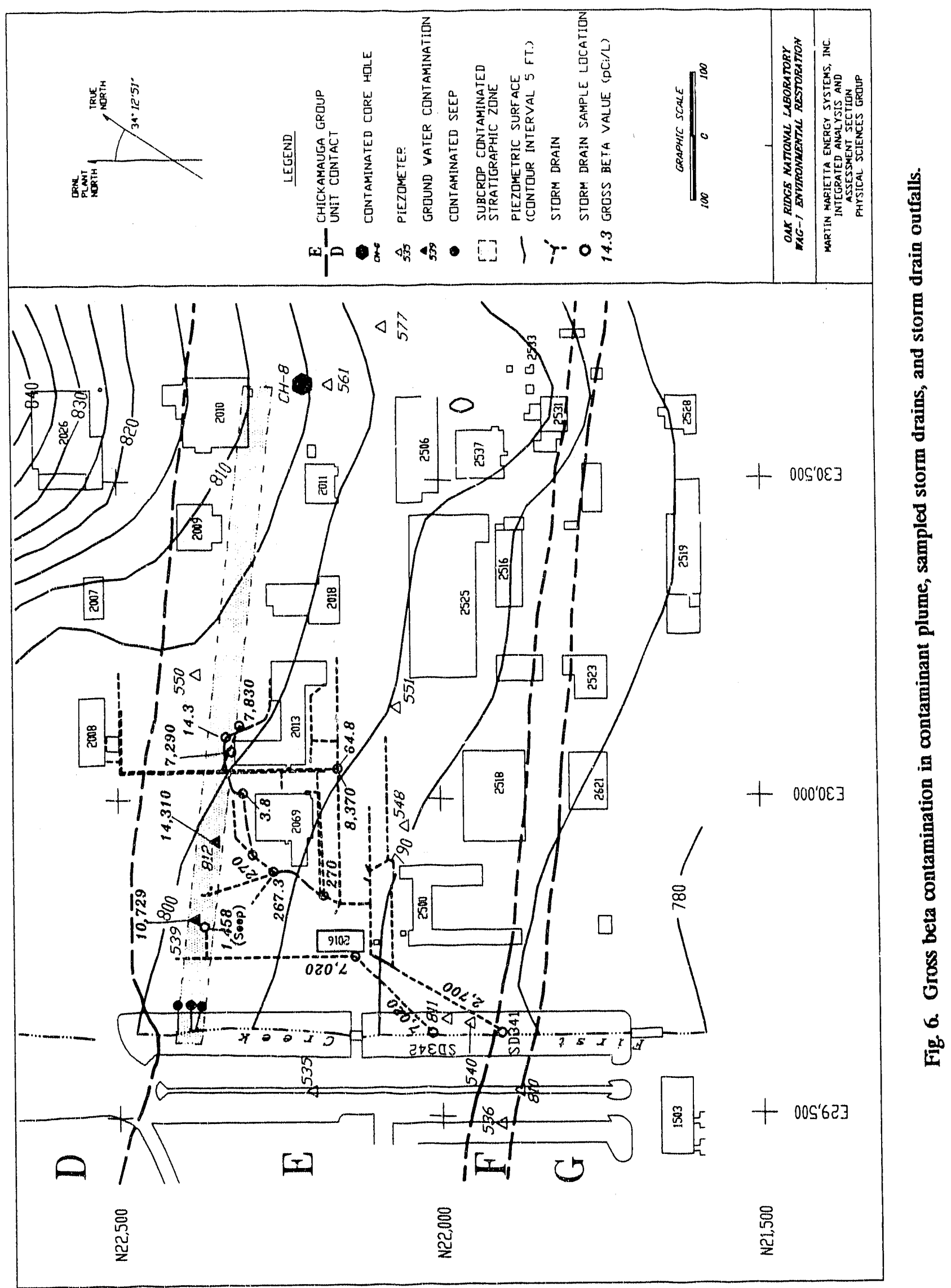


Figure 6 also depicts general characteristics of the groundwatt: flow system that may be used in continued site investigations, conceptual model development, and numerical model analysis. Radiological data indicate that the highest levels of gross beta contamination (by two orders of magnitude) are in CH-8. Conversely, two orders of magnitude higher tritium concentrations occur in piezometers 539 and 812 and outfall 342 . This suggests either (1) a single source area from which highly mobile tritium has largely migrated through the groundwater system while the bulk of the retarded alpha- and beta-emitting contaminants are yet to reach First Creek, or (2) the plume is an admixture of contaminants from more than one source area.

Currently, radiological constituents suggest that the area immediately north of North Tank Farm is a likely source area for alpha and beta contamination. Tritium in piezometer 539 and well 812 may be part of the same plume or may be derived from a separate, currently unidentified source. Continued investigations that include a well-designed subsurface exploration and sampling program as part of Phase II RI/Fs are expected to resolve source area uncertainties and lead to refined conceptual models of the flow field. 


\section{CONCLUSIONS}

The 'vater table gradient (Fig. 4) and Darcian principles would suggest a relatively diffuse contaminant plume migrating in a southerly direction to a First Creek discharge location near its confluence with White Oak Creek. The absence of radiological contaminants in piezometers near and downgradient from $\mathrm{CH}-8$ confirms that local flow and transport are not wholly governed by the overall hydraulic gradient.

The results indicate that the stratabound concept of groundwater flow and contaminant transport in WAG 1 is a viable component of an overall conceptual model of the flow tield. Sole reliance upon Darcian principles to predict local groundwater contaminant plume migration is inadequate in all of the WAG 1 setting. Empirical data now demonstrate that stratabound groundwater flow is operable in three of the four major rock units on ORR-the Conasauga, Knox, and Chickamailga Groups. These data also indicate that groundwater contaminant migration on ORR is an extremely localized phenomenon that is not readily identified or characterized in large-scale studies that assume conventional porous medium conditions.

Detailed analyses of surface and subsurface geologic data lead to the accurate prediction of the location of groundwater contaminant discharge from CH-8 to First Creek in WAG 1. The development of this highly accurate predictive capability can be used to more sharply focus continued groundwater field investigations in WAG 1 and elsewhere on ORR (e.g., down-dip migration). In conjunction with additional working conceptual models, numerical modeling can analyze contaminant source location scenarios and remediation options that are expected to lead to more accurate representations of the WAG 1 flow field and enhanced restoration. 


\section{RECOMMENDATIONS}

Based on the data currently available, it is apparent that contamination is migrating through the bedrock portion of the shallow aquifer beyond the western boundary of WAG 1 and that some fraction of the contaminant plume discharges via the partially lined storm drain system north of Central Avenue. Before design and construciion of any interim plume interception facility, additional data are needed to determine the vertical and areal extent of contamination and to determine the methods of plume control that could be effective.

It is apparent that at least a fraction of this plume is collectible by passive gravity interception. One obvious concept for plume control is to enhance the groundwater collection capability of contaminated portions of the storm drain system and to divert collected groundwater from these areas to treatment, thus reducing the flux of contaminants reaching First Creek.

To determine the vertical and areal extent of contamination, additional groundwater sampling locations are required, including at least one additional core hole suitable for multizone sampling and both shallow and bedrock wells of simple construction capable of yielding samples for radiological analysis. The plume characterization should include a component of investigation west of liirst Creek in the observed plume-transmitting bedrock zone to determine if contaminants are migrating beneath the creek in the bedrock. 


\section{REFERENCES}

Geraghty and Miller, Inc. 1990. Development of Contaminant Transpoit Models for Four Constituents at the S-3 Pond Site, Y-12 Plant, Oak Ridge, Tennessee, Y/Sub/89-00206C/3, Y-12 Plant, Oak Ridge, Tenn.

Lee, R. R., and R. H. Ketelle. 1987. Stratigraphic Influence on Deep Groundwater Flow in the Knax Group Copper Ridge Dolomite on the West Chestnut Ridge Site, ORNL/TM-10479, Oak Ridge National Laboratnry, Oak Ridge, Tennessee.

Lee, R. R., and R. H. Ketelle. 1988. Contaminant Transport Model Validation, ORNL/TM10972. Oak Ridge National Laboratory, Oak Ridge, Tenn.

Lee, R. R., et al. 1989. Calibration of a Groundwater Flow and Contaminant Transport Computer Model: Progress Toward Model Validation, ORNL/TM-11294, Dak Ridge National Laboratory, Oak Ridge, Tenn.

Olsen, C. R., et al. 1983. Chemical, Geological, and Hydrological Factors Governing Radionuclide Migration from a Formerly Used Seepage Trench: A Field Study, ORNL/TM8839, Oak Ridge National Laboratory, Oak Ridge, Tenn.

Olsen, C. R., et al. 1986. "Geochemical and Environmental Processess Affecting Radionuclide Migration from a Formerly Used Seepage Trench, "Geochim. Cosmochim. Acta 30, 593-607. 


\section{DISTRIBUTION}

1. L. D. Bates

2. F. P. Baxter

3. H. L. Boston

4. J. B. Cannon

5. R. B. Clapp

6. K. W. Cook

7. M. F. P. DeLozier

8. R. B. Dreier

9. T. O. Early

10. S. B. Garland

11. C. D. Goins

12. P. J. Halsey

13. R. D. Hatcher, Jr.

14. D. D. Huff

15. S. B. Jones

16. L. L. Kaiser

17-22. R. H. Ketelle

23. B. L. Kimmel

24. F. C. Kornegay

25. A. J. Kuhaida, Jr.

26. D. W. Lee

27-32. R. R. Lee

33. V. Legg
34-36. D. M. Matteo

37. W. M. McMaster

38. G. K. Moore

39-40. P. T. Owen

41. R. M. Reed

42. C. T. Rightmeir

43. P. A. Rubin

44. G. E. Rymer

45. P. A. Scinrandt

46. R. B. Shelton

47. D. K. Solomon

48. M. M. Stevens

49. S. H. Stow

50. D. W. Swindle

51. M. F. Tardiff

52. D. R. Watkins

53. R. K. White

54. T. F. Zondlo

55. Central Research Library

56-60. ER Document Management Center

61-62. Laboratory Records Dept.

63. ORNL Patent Section

64. Office of Assistant Manager for Energy Research and Development, DOE Oak Ridge Field Office, P.O. Box 2001, Oak Ridge, TN 37831-8600

65. G. W. Bodenstein, DOE Oak Ridge Field Office, P.O. Box 2001, Oak Ridge, TN $37831-8540$

66. P. H. Edmonds, Radian Corporation, 120 South Jefferson Circle, Oak Ridge, TN 37830

67-70. R. L. Nace, Department of Energy, Office of Environmental Restoration, Office of Eastern Area Programs, Oak Ridge Program Division, Washington, DC 20585-0002

71. M. Singer, CH2M Hill Co., 599 Oak ?idge Turnpike, Oak Ridge, TN 37830

72-73. R. C. Sleeman, DOE Oak Ridge Field Office, P.O. Box 2001, Oak Ridge, TN 37831-8540

74-75. J. T. Sweeney, DOE Oak Ridge Field Office, P.O. Box 2001, Oak Ridge, TN $37831-8540$

76-77. Office of Scientific and Technical Information, P.O. Box 62, Oak Ridge, TN 37831 

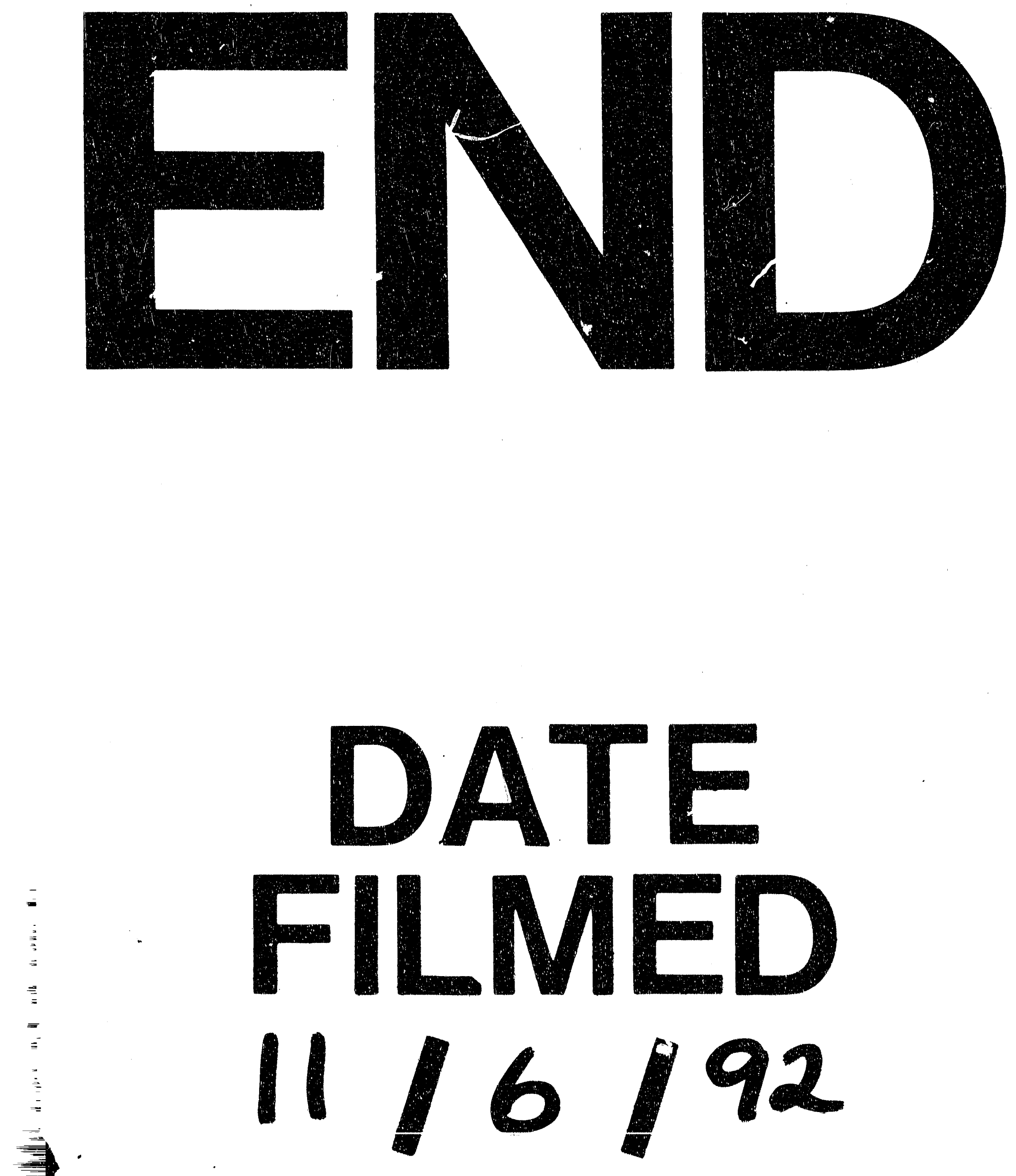
